\title{
METHODS FOR TREATMENT OF DECOMPRESSION SICKNESS DEVELOPED DURING WRECK PENETRATION
}

\section{Ryszard Kłos}

Polish Naval Academy, Diving Gear and Underwater Work Technology Department, Śmidowicza 69 Str., 81-127 Gdynia, Poland; e-mail: r.klos@amw.gdynia.pl

\begin{abstract}
This article is one of the series articles relating to the DiveSMART project conducted to improve coordination procedures used in international underwater rescue operations in the Baltic Sea. The project DiveSMART Baltic has received the 'flagship status'.

The article is the third in the planned cycle of articles relating to efforts made at the Naval Academy within the framework of DiveSMART Baltic project. It includes scenarios of treating decompression sickness acquired by divers during a rescue operation or after completed their decompression. These issues are connected with the work package four 'Medical treatment' of the DiveSMART Baltic project: Identifies methods for different medical treatments in operational areas.
\end{abstract}

Key words:

SAR, underwater search and rescue.

Research article

(C) 2018 Ryszard Kłos

This is an open access article licensed under the Creative Commons Attribution-NonCommercial-NoDerivatives 4.0 license (http://creativecommons.org/licenses/by-nc-nd/4.0/) 


\section{INTRODUCTION}

In the course of diving a situation can occur whose consequence will be the necessity to apply a treatment procedure for divers. It follows from the previous articles that in a search and rescue operation both saturation diving and short-term intervention diving methods will be used. In these two situations, if after decompression the necessity for treatment occurs, some of the treatment procedures mentioned in the article can be applied to not only divers but to survivors rescued from a wreck. However, in most scenarios the treatment procedures will be different, which will be discussed further in the article.

The historical collection of treatment tables TT up to the 1980s can be found in the report by US Naval Medical Research Center [1]. One of the methods available in the review literature is the classification agreed upon in NATO. The complete list of the TT used by individual countries is presented in Chapter 5 National therapeutic recompression tables [9]. This document is the Annex to the NATO Standardization Agreement [18].

Tab. 1. Example of treatment tables TT apportionment [1]

\begin{tabular}{|c|c|c|}
\hline Type & $\begin{array}{c}\text { Example of national } \\
\text { tables }\end{array}$ & $\begin{array}{c}\text { Equivalent US Navy } \\
\text { tables }\end{array}$ \\
\hline Short oxygen tables & TABLE V & \\
& Goodman 1 (BE) & \\
OHB (FR) & TT USN 5 \\
& HBO (GE) & \\
& 60 \& 61 (UK) & \\
\hline Long, shallow oxygen & TABLE VI & \\
tables & 62 (UK) & TT USN 6 \\
& Goodman 2 (BE) & \\
\hline Long, deep oxygen & TABLE VII & \\
tables & 6A (mod) (GE, CA) & \\
& TABLES A and B (FR) & TT USN 6A \\
& SND (GE) & \\
\hline Saturation & TABLE VIII & \\
or sub-saturation & US 7 & \\
tables & US 8 & TT USN 4 \\
& TABLE C (FR) & \\
\hline Air tables & 64 \& 65 (UK) & \\
& TABLE I & \\
& TABLE II & 1A \\
& TABLE D (FR) & 2A \\
& 52 (UK) & \\
\hline
\end{tabular}


The existing TT can be divided into saturation, sub-saturation, and outside the saturation zone TT (tab. 1). And the last mentioned TT can be divided into those using oxygen therapy or other therapy 1 .

The US Navy procedures [21] constitute the most widespread treatment system $^{2}$. An interesting extension of air treatment procedures is the set of the airhelium $^{3}$ tables developed by Russians [24]. However, the system which can support the whole, available for divers at present, range of depths is the system developed by COMEX [17].

\section{TREATMENT PROCEDURES}

There exist different classifications of decompression sickness $D C S^{4}$. The classification proposed by Wienke has been adopted here (tab. 2). The most common cases encompass: Type I DCS and Type II DCS. They are caused by formation of gas in free phase in tissues. They can be effectively treated by hyperbaric methods causing decrease in the size of bubbles in free gas phase occurred into tissues and caused the possibility of their reabsorption and elimination by the gas exchange through the blood into the respiratory system.

Tab. 2. Types of decompression sickness DCS [22]

\begin{tabular}{|c|l|}
\hline Type I & $\begin{array}{l}\text { Limbs. Symptoms: localized pain in joints, skin itching, bends, rashes, mottling, } \\
\text { lymphatic swelling, ascending weakness in the legs, hips, elbows, muscles or } \\
\text { skin }\end{array}$ \\
\hline Type II & $\begin{array}{l}\text { Central nervous system. Symptoms: confusion, anxiety, paralysis, dyspnoea, } \\
\text { chest pain, breathing difficulty, loss of conscientiousness, lack of alertness, impaired } \\
\text { balance problems in keeping upright posture, especially keeping the spine } \\
\text { straight }\end{array}$ \\
\hline Type III & $\begin{array}{l}\text { Inner ear. Symptoms: impaired hearing, dizziness, ringing in the ears, and } \\
\text { tinnitus or nausea. It is the result of the impact of pressure on keeping balance } \\
\text { in the organs in the ear }\end{array}$ \\
\hline Type IV & $\begin{array}{l}\text { Avascular necrosis. Symptoms: mechanical bone injury, structural injury, } \\
\text { local mineralization. It affects mostly long bones }\end{array}$ \\
\hline
\end{tabular}

${ }^{1}$ Air, air-helium, helium-oxygen $H x$ tables.

${ }^{2}$ Understood as a method for moving between the treatment procedures in the course of treatment decompression or when next sickness symptoms occurred after the completion of treatment.

${ }^{3}$ Oxygen-nitrogen-helium mixture is called Trimix and marked $T x$.

${ }^{4}$ Decompression Sickness. 
In the traditional operational diving 5 Type I DCS is most often caused by formation of gas in free phase in tissues, especially in blood, adipose and connective tissue and Type II DCS in nervous tissue. Blocked flow of blood by gas free phase can cause local ischemia leading to necrosis. Occurrence of gas in free phase in tissue usually causes neurological symptoms.

There exist a few theories relating to the probable pain inducing mechanism with regard to Type I DCS [10]. It occurs when bubbles in gas in free phase reach the size big enough to:

- dislocate or irritate nerve endings;

- block capillaries leading to ischemia and tissue necrosis, which while excreting chemical substances warn the brain about injuries inducing feeling of pain generated by brain;

- activate the biochemical reaction of immunoglobulins production, which also stimulates pain signaling the presence of harmful substances in living cells.

The destructive actions in tissues caused by gas existing in free phase are not the only pathological symptoms induced by it. Defensive reactions of an organism induced by gas in free phase do not have to be directly linked to the mechanical impact, but they also have biochemical origins of pain. This theory, called the complement activation ${ }^{6}$, seems to be well documented [12].

Type II DCS can be a result of blocked blood flow to the spinal cord, which causes slowing down stimulation or inhibiting higher brain functions?

Type III DCS can be caused by gas in free phase, inert gas counterdiffusion and increased pressure of bodily fluids in the inner ear. Theoretically, anomalies occurring on the surface of cell membranes can be responsible for Type III DCS, and counterdiffusion caused by occurrence of content gradients of various gases is responsible for these anomalies. One gas can defund in one direction, whereas the other in the opposite direction. Their counter-current streams cause gas exchange disturbances on the borders of phases, which causes a change in physical conditions of gas solubility in tissue ${ }^{8}$ [15]. Their mutual competing for presence in the solution

5 Outside the saturation zone.

${ }^{6}$ Complement is a system of plasma proteins contributing to defensive reaction of that occurs on the surface of pathogens and generates active components with various effector functions.

${ }^{7}$ Central nervous system does not tolerate becoming deprived of the flow of information, that is why its activity dies out quickly, causing Type II DCS.

${ }^{8}$ Natural solubility is understood here as the condition in which gases occur independently. 
can lead to displacing one of them ${ }^{9}$ [16]. Type III DCS symptoms can be a result of an osmotic reaction. Bodily fluids tend to balance the concentration of gases contained in it through dislocation, causing dilution of the more concentrated solution. This can entail an increase in the amount of fluids in the inner ear organs which leads to dysfunction of the labyrinth as a consequence [2].

It is difficult to determine to what extent Type IV DCS is caused by wrongly performed decompression. Its formation can be influenced by the free gas phase, ischemia, embolism ${ }^{10}$ and a combination of these factors. Statistically this sickness is important with regard to professional divers and people working in caissons. Both of these groups are often exposed to high pressure actions. The same symptoms as in Type IV DCS are found in racing horses and alcoholics. In this case, this sickness is called aseptic bone necrosis. The mechanisms of formation of Type IV DCS are considered theoretically and there is no exhaustive evidence based on medical observation. These symptoms are osteonecrosis that is not induced by infection ${ }^{11}$. If pathological hardening of bone occurs in the central part it does not affect vitals. If pathological changes occur in the end of a bone, where the head of one of the bones fits into the socket of another one, splinters can form and joints can be damaged. Probably, repeated fast compression and the content of dioxide can have an influence on inducing avascular osteonecrosis. Long exposition to partial oxygen pressure above $60 \mathrm{kPa}$ can cause osteonecrosis in people predisposed to developing this sickness. The probable mechanism is associated with blocking blood flow into marrow and living bone tissue by bubbles in gas in free phase, locating themselves in capillary vessels [22]. An connection has been found of pain located in bones region with the yellow marrow, which is far less supplied by blood ${ }^{12}$ than the red marrow. Connecting this with the generally known good solubility of inert gases in fats it can be anticipated that the difficulty in transporting the gas from the inside of a bone can be the cause of the sickness symptoms.

Type III DCS and Type IV DCS should not be treated with hyperbaric methods using recompression treatment. In many cases, recompression treatment can lead to worsened condition of a patient [20]. It is important as Type II DCS and Type III DCS are difficult to distinguish from each other.

\footnotetext{
${ }^{9}$ Mechanism similar to the salting-out effect in water solutions; the addition of sodium chloride to a another solution to reduce the solubility of the latter.

10 Gas embolism.

11 Hence the term aseptic.

12 Perfunded.
}

1 (212) 2018 
During saturation dives Type I DCS can occur after an excursion to the depth less than the plateau of saturation or during decompression on completion of saturation. The symptoms are pain in skeletal muscle areas and joint or joints, especially knee joints. It can be preceded by itching, a rash or skin spots. Most often, at the beginning increased stiffness occurs in a knee joint area hindering movement. Then, within a few hours, the pain steadily grows in joint areas. However, divers should be able to distinguish the pain, which occurs as a result of small injuries or after some physical effort, caused by joint overload or mechanical injuries which occur during work from which the cause may be related to decompression. To this end, it is necessary to thoroughly consider the history of pain formation and its increase. It is little likely that the pain which occurred before the beginning of the decompression was caused by DCS. Type I DCS formed during an excursion from the plateau of saturation and up to $60 \mathrm{~min}$ after the excursion over the depth of the plateau of saturation should be regarded as type II DCS, because type I DCS symptoms are most often a signal of more serious complications.

Treatment of symptoms of diving sicknesses during saturation differs from that administered after completed decompression following saturation diving and operational diving outside the saturation zone [11]. Usually the treatment methods in saturation can also be applied as the final DCS treatment methods following diving beyond the saturation zone, as in the system developed by Comex [17]. The effectiveness of saturation treatment methods should be the highest than other ones, but they are long-term methods and that is why treatment using treatment tables can be performed more effectively. Hence the US Navy system is most common [21].

An almost complete historical review of the most important trends in the progress recorded with regard to the decompression sickness treatment can be found in some many places, but it is easy to find it in the Internet, on the webpage address $^{13}$ : http://www.wikiwand.com/en/Hyperbaric_treatment_schedules. Here a set of tables will be presented, implemented in the US Navy and used by many NATO countries together with other methods, which are interesting from the point of view of the DiveSmart project.

${ }^{13}$ Access June 2017. 
Time $[\mathrm{min}]$

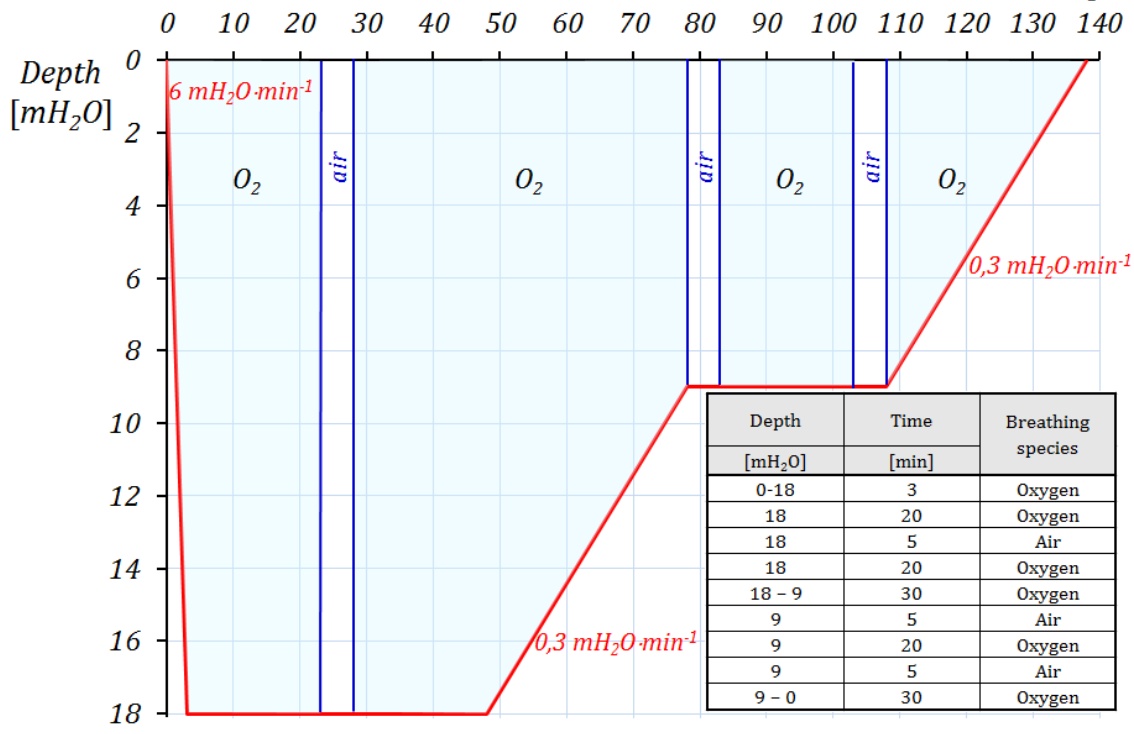

Fig. 1. Treatment table TT 5 USN [1]

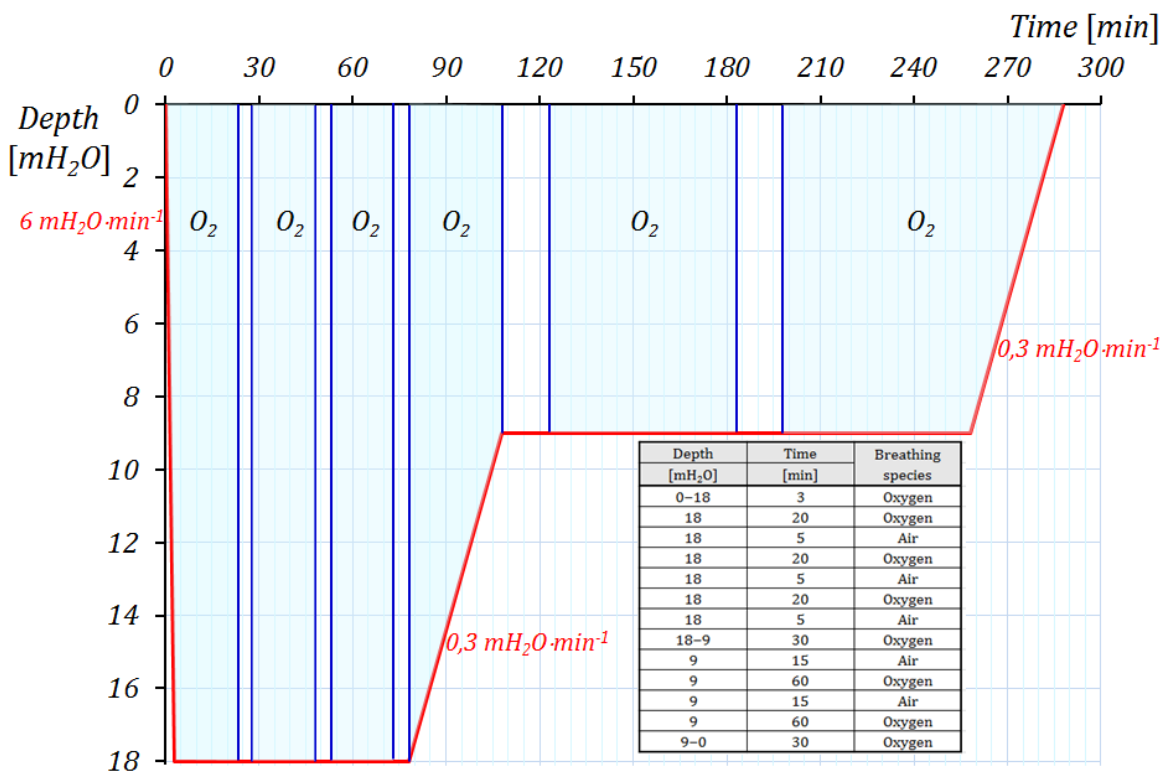

Fig. 2. Treatment table TT 6 USN [1] 


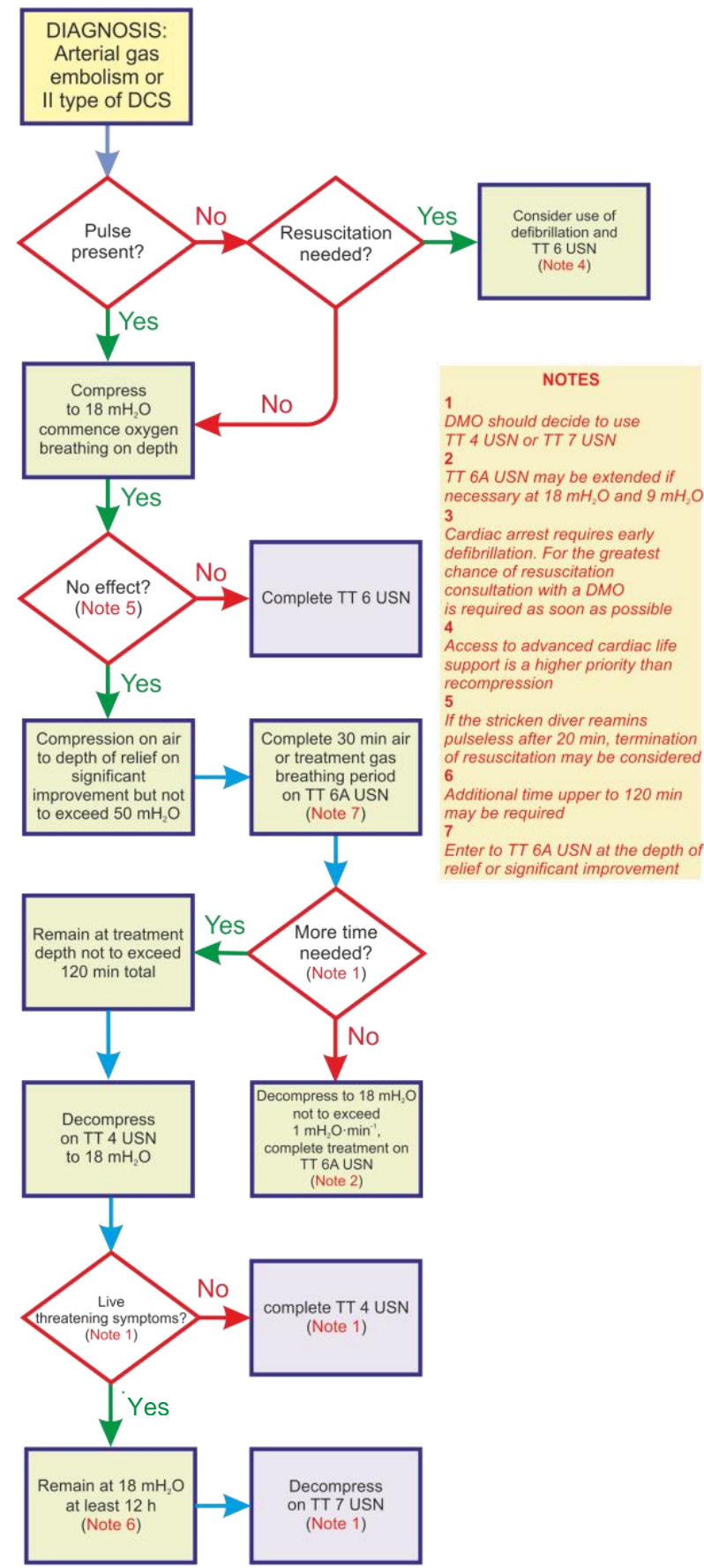

Fig. 3. Algorithm for treatment of gas embolism Type II DCS [own study based on 1] 


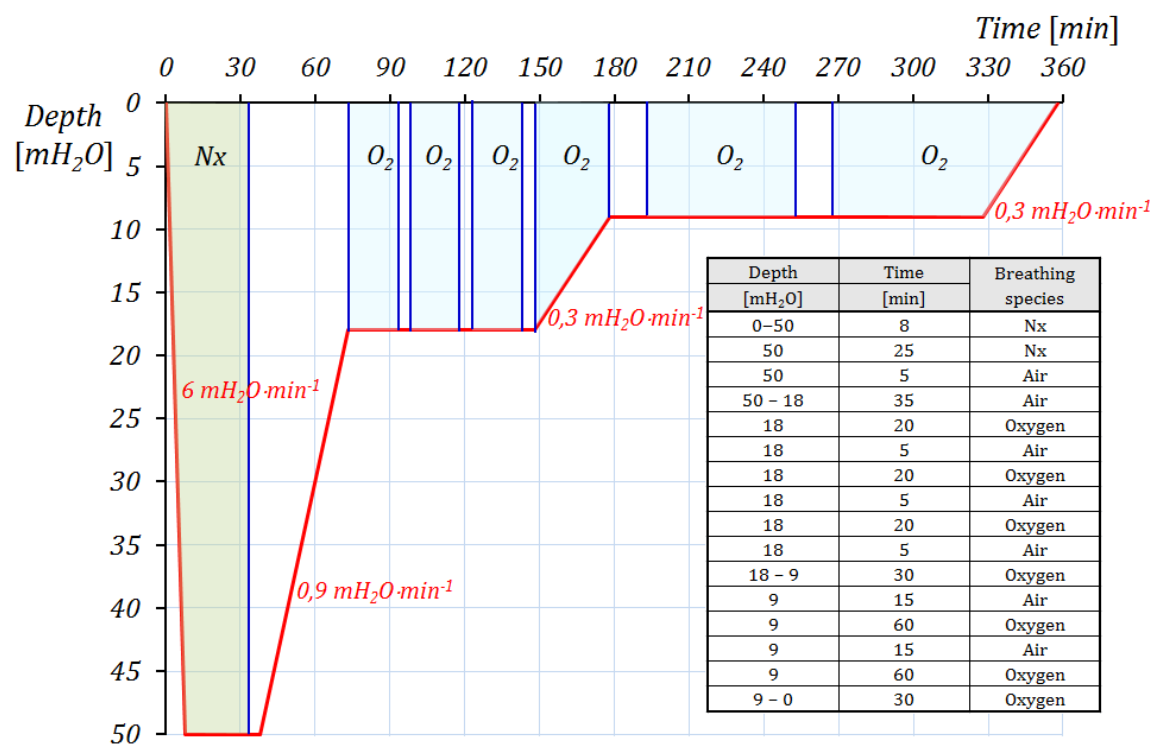

Fig. 4. Treatment table TT $6 A$ USN [1]

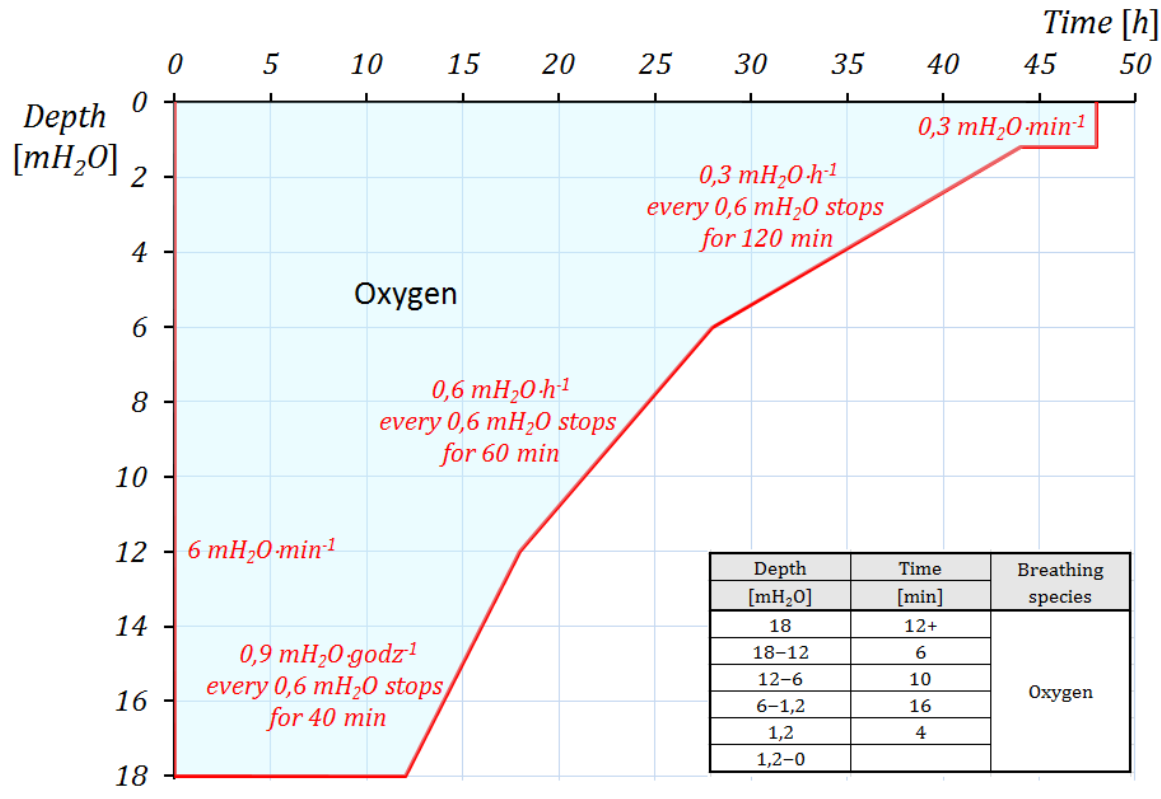

Fig. 5. Treatment table TT 7 USN [1] 


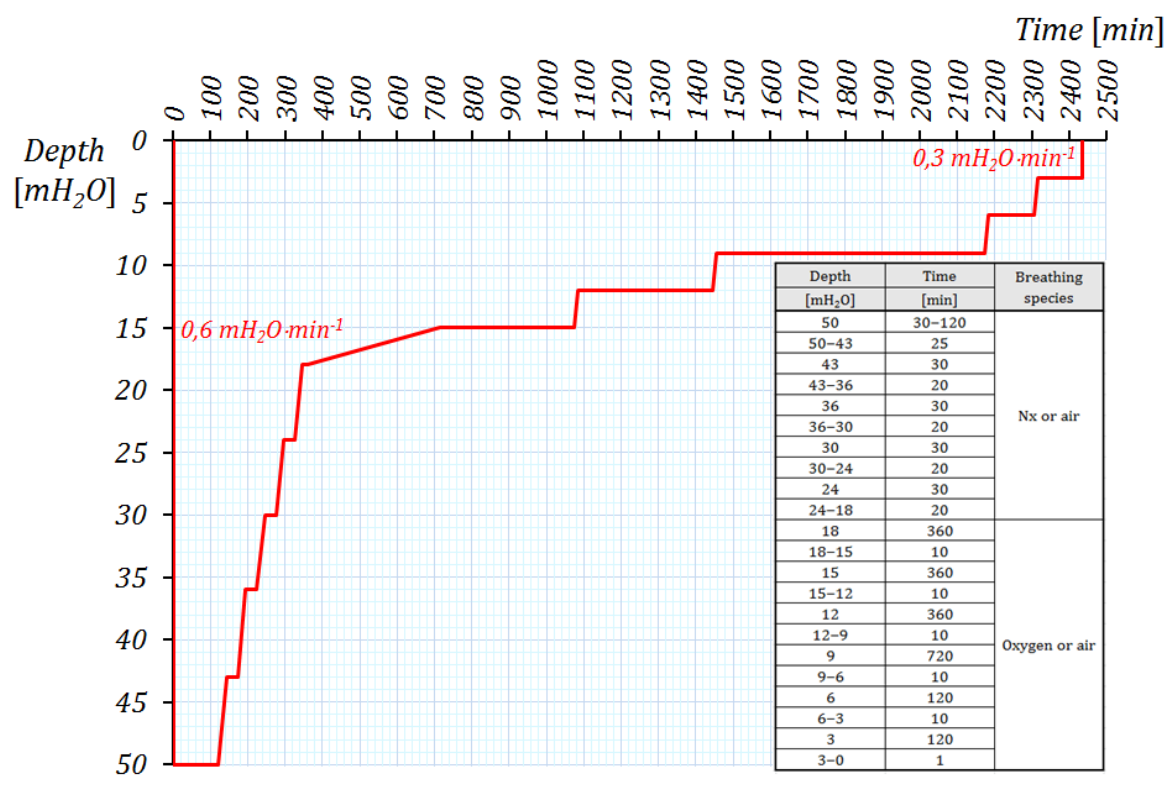

Fig. 6. Treatment table TT 4 USN [1]

\section{US NAVY TREATMENT TABLES}

The set of treatment tables USN, implemented the US Navy, encompasses procedures using only air ${ }^{14}$ or air and $N x^{15}$, and procedures using both air $/ N x$ and oxygen alternately ${ }^{16}$ as treatment breathing agents [21]. Procedures utilizing oxygen are more effective and should be administered first. Procedures utilizing air only should be administered when oxygen is not available ${ }^{17}$, in emergency conditions, where the patient does not tolerate oxygen under high pressure ${ }^{18}$ and he shows symptoms of oxygen toxicity during the treatment or the occurrence of oxygen toxicity is highly probable ${ }^{19}$.

\footnotetext{
141 A TT USN, $2 A$ TT USN, and 3 TT USN.

${ }^{15} N x 7$ TT USN; nitrogen-oxygen mixture is called Nitrox and is marked $N x$.

164 TT USN, 5 TT USN, 6 TT USN, 6A TT USN, 9 TT USN.

17 E.g. as a result of built-in-breathing system malfunction, exhaustion of stocks, etc.

${ }^{18}$ Develops oxygen toxicity [21].

${ }^{19}$ Considered when the diver was, just before, exposed to high partial pressure of oxygen and in this case occurrence of symptoms indicating central nervous system oxygen toxicity or pulmonary oxygen toxicity is highly probable, e.g. when the dose of oxygen toxicity was clearly
} exceeded during the dive $[10,13,14]$. 


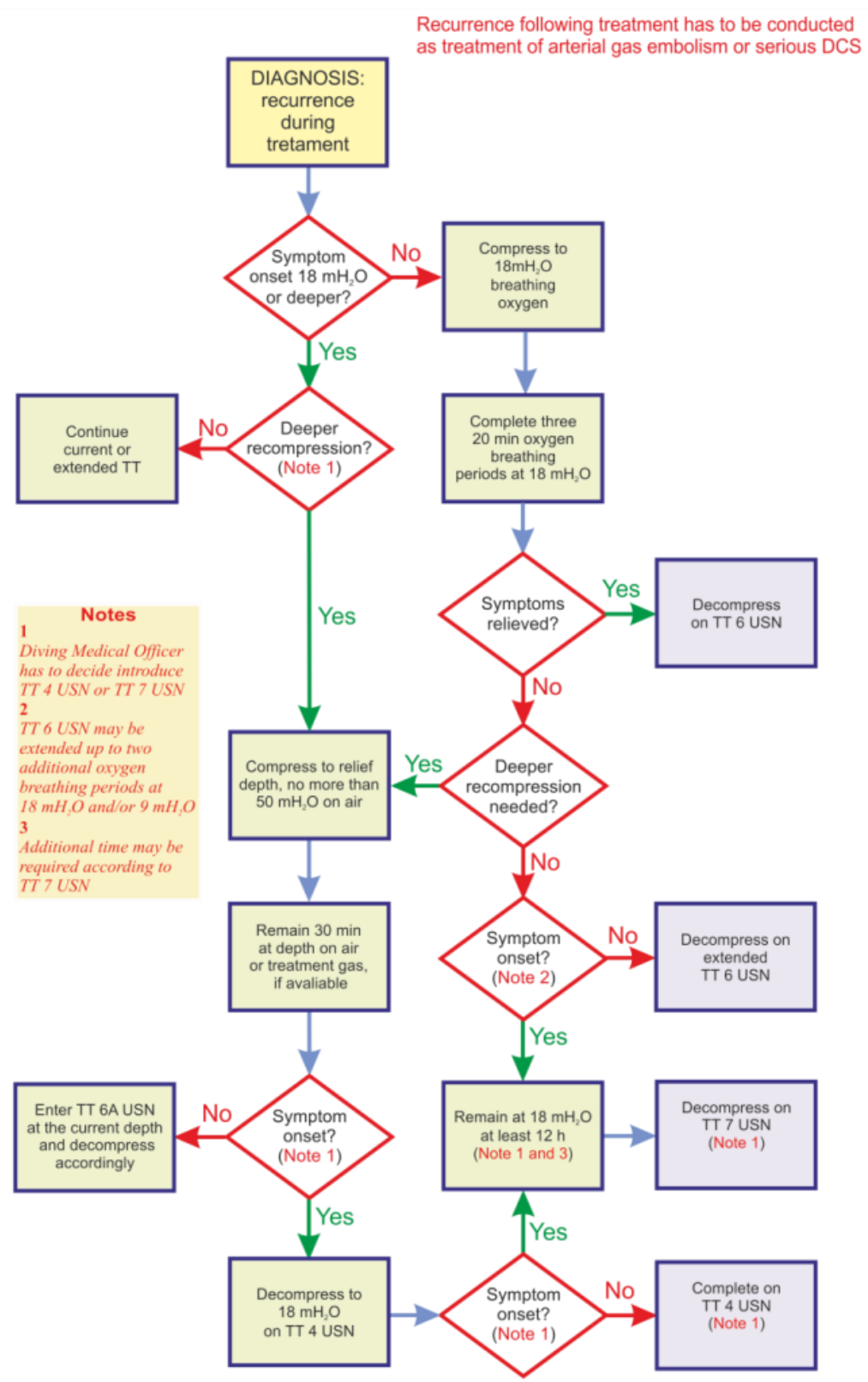

Fig. 7. DCS recurrence treatment algorithm [own study based on 1]

To treat Type I DCS the TT 5 USN is used (fig. 1). If after $\tau=10 \mathrm{~min}$ of stop at the depth $\mathrm{H}=18 \mathrm{mH}_{2} \mathrm{O}$ the sickness symptoms do not disappear, the treatment has to be continued using the TT 6 USN (fig. 2). If after $\tau=10 \mathrm{~min}$ of stop at the depth 
$\mathrm{H}=18 \mathrm{mH}_{2} \mathrm{O}$ the sickness symptoms disappear, the treatment can be discontinued in accordance with the TT 5 USN or it can be prolonged by maximum two cycles $\tau_{\mathrm{O}_{2}}=20 \mathrm{~min}$ cycle of breathing oxygen and $\tau_{\text {air }}=5 \mathrm{~min}$ cycle of breathing air at the depth $\mathrm{H}=9 \mathrm{mH}_{2} \mathrm{O}$. Treatment using the TT 6 USN can be prolonged by two $\tau_{\mathrm{O}_{2}}=20 \mathrm{~min}$ cycles of breathing oxygen and $\tau_{\text {air }}=5 \mathrm{~min}$ breathing air at the depth $\mathrm{H}=18 \mathrm{mH}_{2} \mathrm{O}$ and two $\tau_{\mathrm{O}_{2}}=20 \mathrm{~min}$ cycles of breathing oxygen and $\tau_{\text {air }}=5 \mathrm{~min}$ breating with at the depth of $\mathrm{H}=9 \mathrm{mH}_{2} \mathrm{O}$. More serious cases, such as Type II DCS, are treated following the algorithm presented in figure 3. To treat gas embolism or Type II DCS treatment tables: 4 TT USN, 6A TT USN, 7 TT USN are used. They are shown in figures 4-6, and the procedure in figure 7.

Treatment table TT $1 A U S N$ is used to treat light symptoms of DCS, when the depth of relief does not exceed $20 \mathrm{mH}_{2} \mathrm{O}$ (fig. 8). Tables TT $2 A$ USN, and TT 3 USN are used interchangably to treat more serious cases (fig. 9 and 10). When the depth of relief exceeds $50 \mathrm{mH}_{2} \mathrm{O}$, the TT $4 U S N$ should be used (fig. 6).

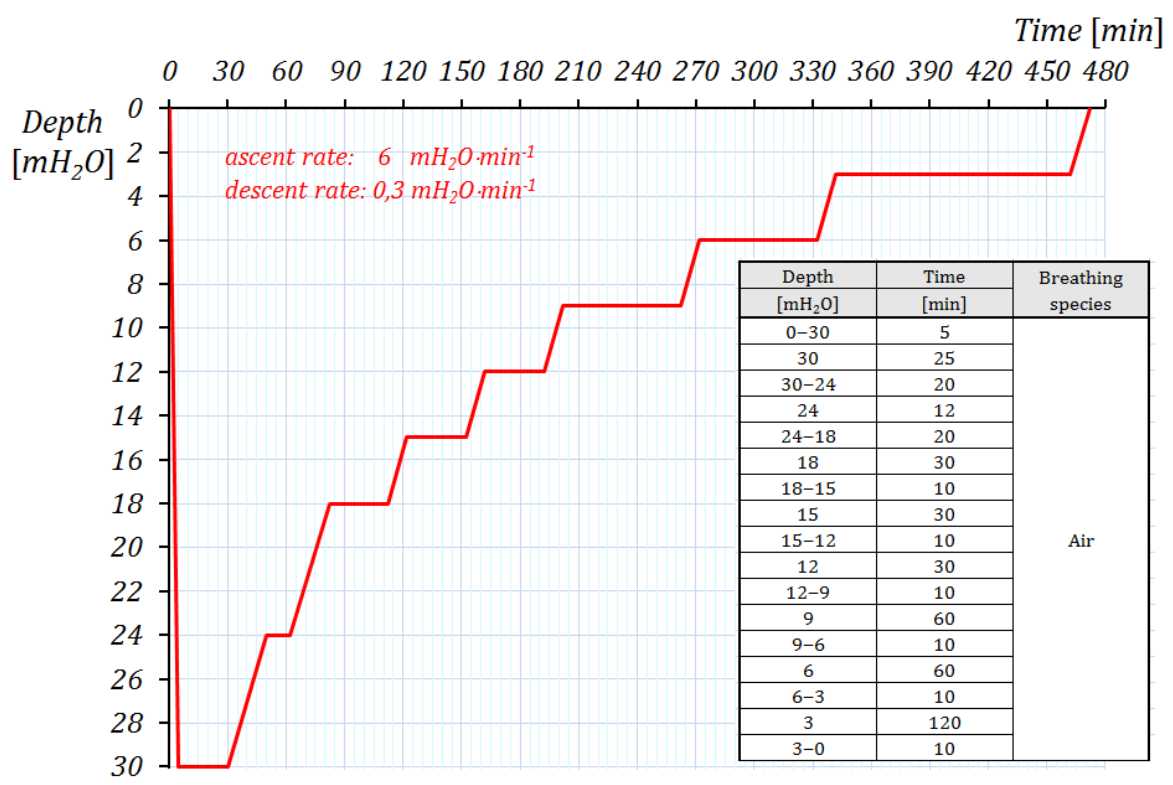

Fig. 8. Treatment table TT $1 A$ USN [1] 


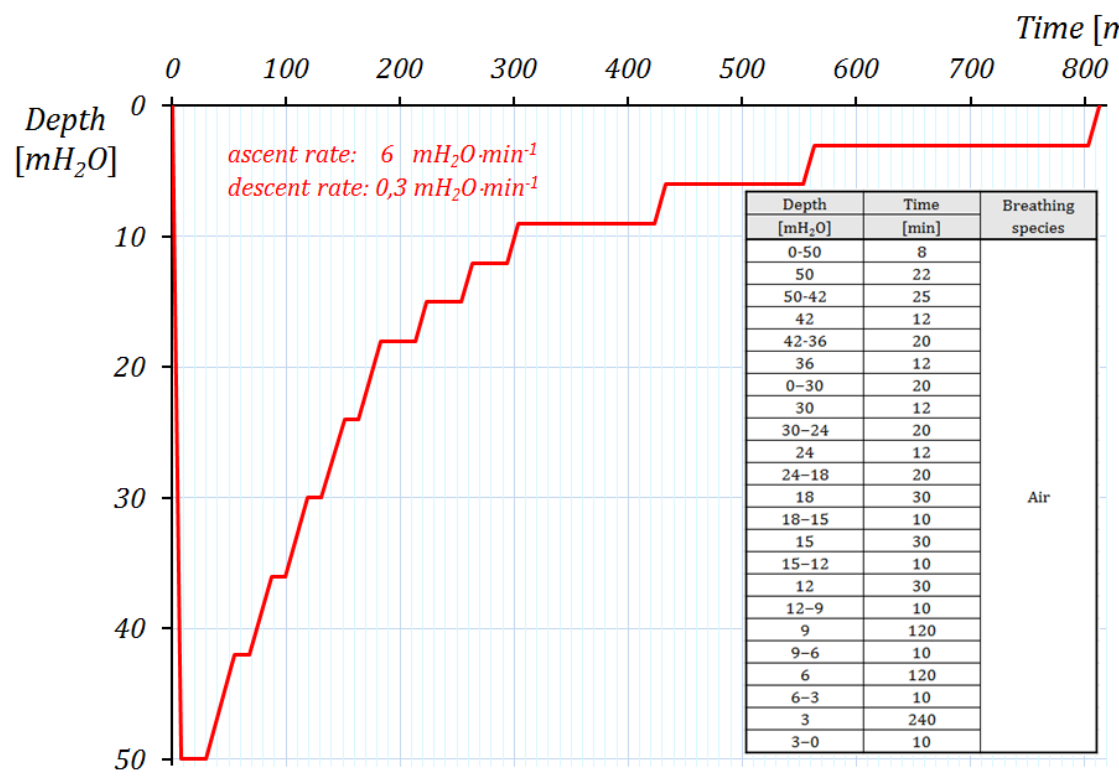

Fig. 9. Treatment table TT $2 A$ USN [1]

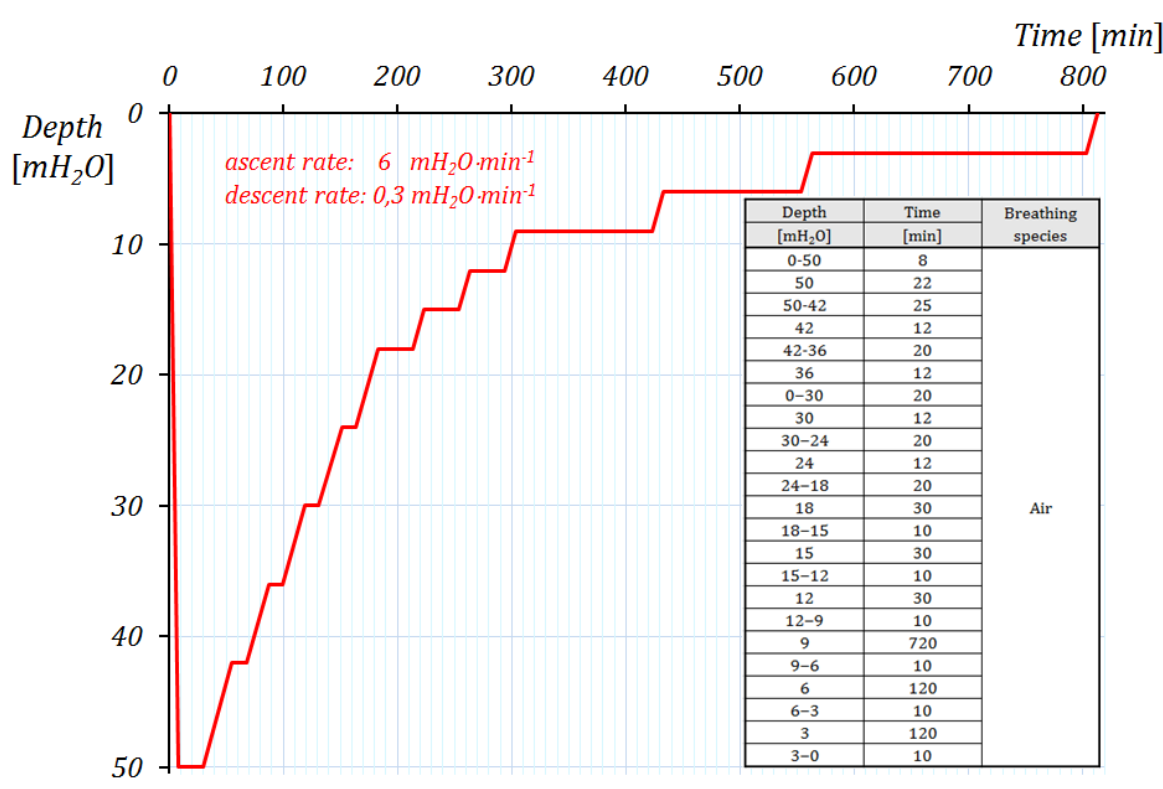

Fig. 10. Treatment table TT 3 USN [1] 


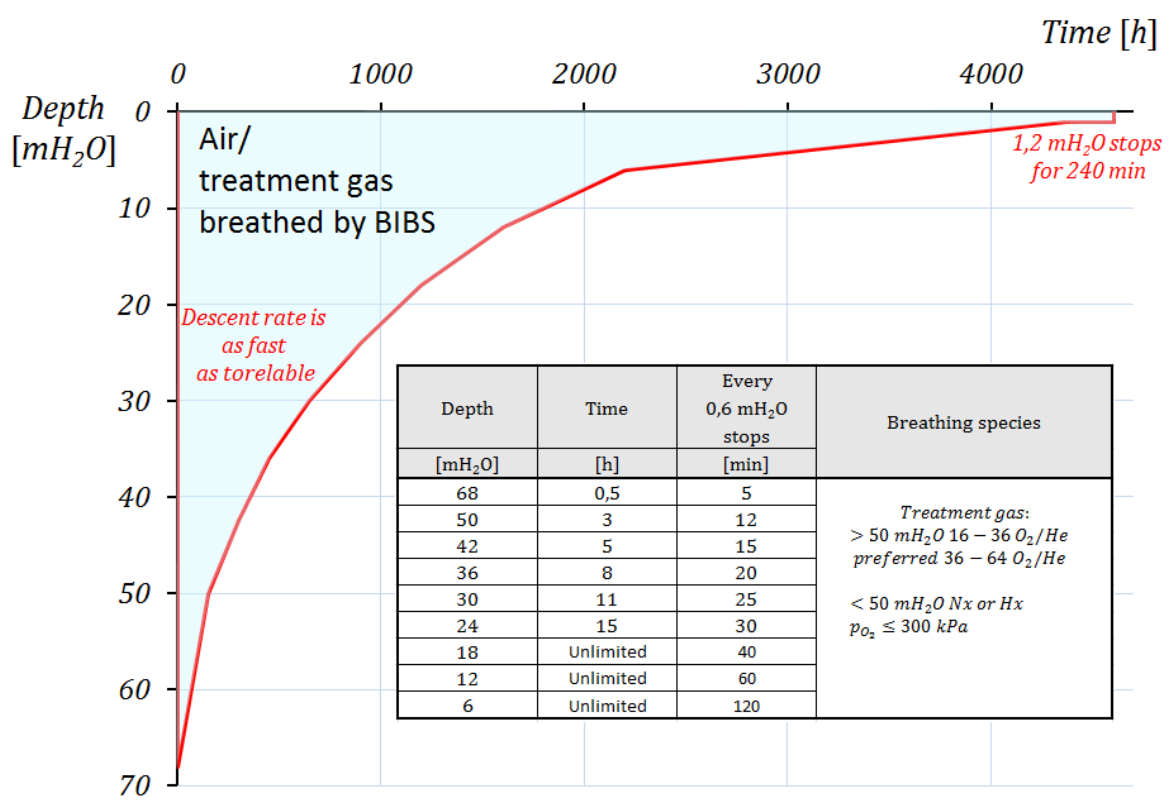

Fig. 11. Treatment table TT 8 USN /RN 65 [1]

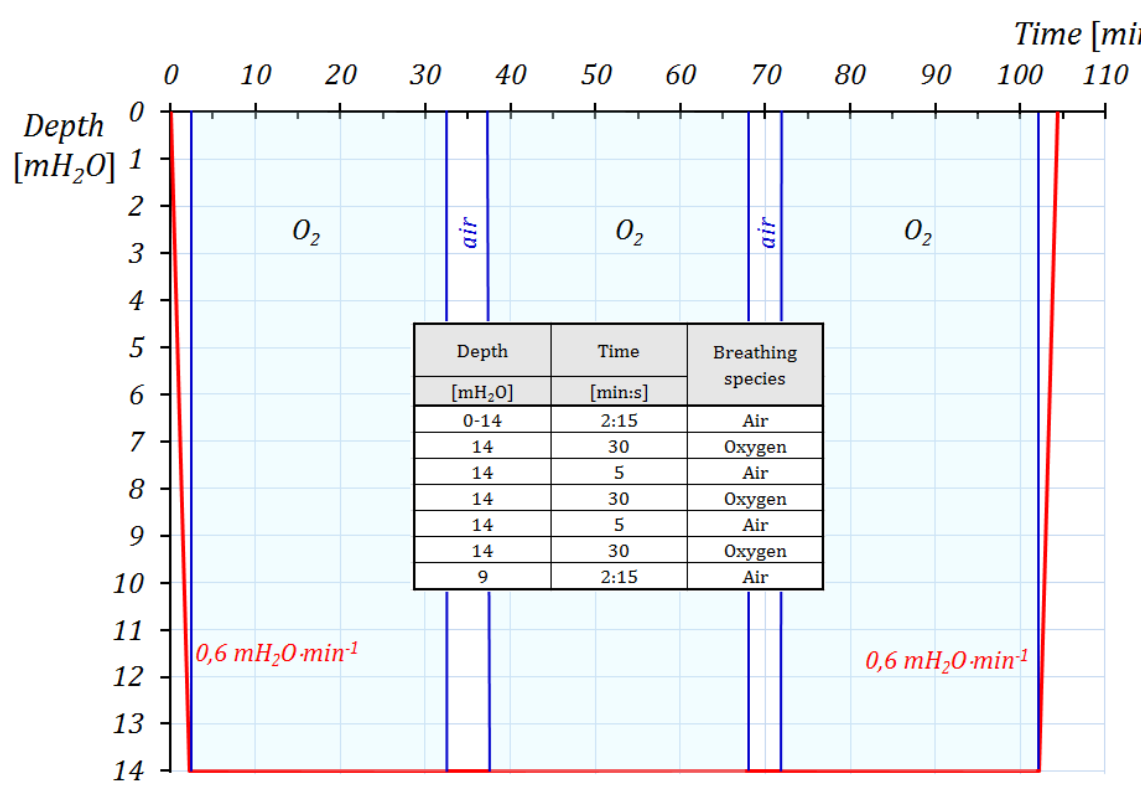

Fig. 12. Treatment table TT 9 USN [1] 
The supplement to the DCS treatment system are two US Navy tables: TT 8 USN and TT 9 USN. The TT 8 USN is an adaptation of the TT 65 RN used in the DCS treatment system by the Royal Navy and can be used when decompression stations have been omitted or the diver is thrown to the surface in an uncontrollable way. The TT 8 USN starts with compressing the diver to the depth of relief, but not higher than $68 \mathrm{mH}_{2} \mathrm{O}$ (fig. 11). The TT $9 \mathrm{USN}$ is used to treat mild DCS symptoms following the previous treatment (fig. 12). It is also used to treat cases of carbon monoxide poisoning or poisoning by exhaust fumes.

\section{RUSIAN AIR TREATMENT TABLES}

An interesting supplement system to the methods for air DCS treatment used by the US Navy are treatment tables air $/ T x^{20}$ proposed by Военно Морский Флот России which provide a capability of reaching the pressure of relief up to the depth of $100 \mathrm{mH}_{2} \mathrm{O}$ [24] (tab. 3).

Russian treatment tables TT I BMФ - TT III BM $\Phi$ are tables which use only air $/ O_{2}$ as the treatment agent. The TT I BMФ is dedicated to treating light symptoms of decompression sickness Type I DCS which disappear below the depth of $30 \mathrm{mH}_{2} \mathrm{O}$ during compression. The TT II BMФ is dedicated to treating light symptoms of decompression sickness Type I DCS, where the depth of relief occurs below the depth of $50 \mathrm{mH}_{2} \mathrm{O}$ during compression. The TT III BMФ is dedicated to treating mean symptoms of decompression sickness Type I DCS.

Treatment tables TT IV ВM $\Phi$ - TT V BM $\Phi$ are tables using Tx as the treatment agent, because from the depth of $70 \mathrm{mH}_{2} \mathrm{O}$ pure helium or $\mathrm{Hx}^{21}$, having the content of helium within $\mathrm{Hx}$ : [18; 20] $\%_{v} \mathrm{O}_{2} / \mathrm{He}$, are used for compression. The TT IV ВMФ is used to treat severe forms of decompression sickness Type I DCS and the TT V BMФ to treat neurological Type II DCS symptoms.

\footnotetext{
${ }^{20}$ Nitrogen-helium-oxygen mixture called Trimix.

21 Helium-oxygen mixture called Heliox.
} 
Tab. 3A. Russian air/oxygen treatment tables [24]

\begin{tabular}{|c|c|c|c|c|c|c|c|c|c|c|c|c|c|c|c|c|c|}
\hline \multirow{4}{*}{ 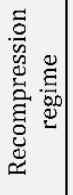 } & \multirow{4}{*}{ 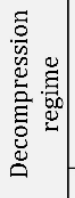 } & \multirow{3}{*}{ 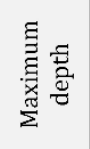 } & \multirow{3}{*}{ 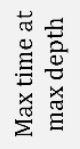 } & \multirow{3}{*}{ 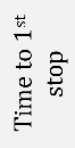 } & \multirow{3}{*}{ 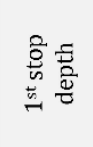 } & \multirow{3}{*}{ 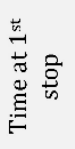 } & \multirow{3}{*}{ 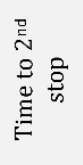 } & \multicolumn{10}{|c|}{ Next decompression stops $\left[\mathrm{mH}_{2} \mathrm{O}\right]$} \\
\hline & & & & & & & & 30 & 28 & 26 & 24 & 22 & 20 & 18 & 16 & 14 & 12 \\
\hline & & & & & & & & \multicolumn{10}{|c|}{ Time at next decompression stops } \\
\hline & & {$\left[\mathrm{mH}_{2} \mathrm{O}\right]$} & {$[\mathrm{min}]$} & {$[\mathrm{min}]$} & {$\left[\mathrm{mH}_{2} \mathrm{O}\right]$} & {$[\mathrm{min}]$} & {$[\min ]$} & \multicolumn{10}{|c|}{$[\mathrm{min}]$} \\
\hline \multirow{4}{*}{ I } & $\begin{array}{ll}\mathrm{A} \\
\end{array}$ & \multirow{4}{*}{50} & 60 & \multirow{4}{*}{20} & \multirow{4}{*}{30} & \multirow{3}{*}{30} & 20 & & & & & & & & & & \\
\hline & Б & & 120 & & & & 14 & & & & & & & & 107 & 202 & 245 \\
\hline & B & & 180 & & & & 10 & & & & & & 101 & 166 & 182 & 202 & 245 \\
\hline & $\Gamma$ & & 360 & & & 73 & 2 & & 106 & 112 & 121 & 130 & 152 & 166 & 182 & 202 & 245 \\
\hline \multirow{3}{*}{ II } & A & \multirow{3}{*}{70} & 60 & \multirow{3}{*}{20} & \multirow{3}{*}{50} & \multirow{3}{*}{30} & 32 & & & & & & & 65 & 182 & 203 & 245 \\
\hline & Б & & 90 & & & & 28 & & & & & 39 & 164 & 179 & 196 & 218 & 262 \\
\hline & B & & 120 & & & & 24 & & & 75 & 131 & 140 & 164 & 179 & 196 & 218 & 262 \\
\hline \multirow{3}{*}{ III } & A & \multirow{3}{*}{100} & \multirow{3}{*}{15} & \multirow{3}{*}{30} & \multirow{3}{*}{70} & 60 & 46 & & & & 113 & \begin{tabular}{|l|}
152 \\
\end{tabular} & \begin{tabular}{|c|}
164 \\
\end{tabular} & \begin{tabular}{|l|}
178 \\
\end{tabular} & 196 & \begin{tabular}{|l|}
218 \\
\end{tabular} & 262 \\
\hline & Б & & & & & 90 & 42 & & 63 & 132 & 140 & 152 & 164 & 178 & 196 & 218 & 262 \\
\hline & $\mathrm{B}$ & & & & & 120 & 40 & 113 & 123 & 132 & 141 & 152 & 164 & 178 & 196 & 218 & 262 \\
\hline
\end{tabular}

Tab. 3A cont. Russian air/oxygen treatment tables [24]

\begin{tabular}{|c|c|c|c|c|c|c|c|c|c|}
\hline \multirow{4}{*}{ 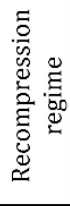 } & \multirow{4}{*}{ 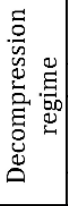 } & \multicolumn{5}{|c|}{ Next decompression stops $\left[\mathrm{mH}_{2} \mathrm{O}\right]$} & \multirow{2}{*}{\multicolumn{3}{|c|}{ Total time }} \\
\hline & & 10 & 8 & 6 & 4 & 2 & & & \\
\hline & & \multicolumn{5}{|c|}{ Time at next decompression stops on air (B) or $\mathrm{O}_{2}$} & air & $\mathrm{O}_{2}$ & Totality \\
\hline & & \multicolumn{5}{|c|}{$[\mathrm{min}]$} & \multicolumn{2}{|c|}{$[\mathrm{min}]$} & {$[h: \min ]$} \\
\hline \multirow{7}{*}{ I } & \multirow{2}{*}{ A } & $30+140 \mathrm{~B}$ & $30 \mathrm{~B}+60$ & $90 \mathrm{~B}+60$ & $180 \mathrm{~B}+60$ & $60 \mathrm{~B}+60$ & 570 & 270 & $14: 00$ \\
\hline & & $247 \mathrm{~B}$ & $305 \mathrm{~B}$ & $368 \mathrm{~B}$ & 235 в & 235 в & 1460 & - & $24: 20$ \\
\hline & \multirow{2}{*}{ Б } & \multirow{2}{*}{$280 \mathrm{~B}$} & $60+35 \mathrm{~B}$ & $105 \mathrm{~B}+60$ & $210 \mathrm{~B}+60$ & $70 \mathrm{~B}+60$ & 1318 & 240 & $25: 58$ \\
\hline & & & $328 \mathrm{~B}$ & 396 в & 253 в & 253в & 2128 & - & $35: 28$ \\
\hline & \multirow{2}{*}{ B } & \multirow{2}{*}{$280 \mathrm{~B}$} & $60+35 \mathrm{~B}$ & $105 B+60$ & $210 B+60$ & $70 \mathrm{~B}+60$ & 1656 & 240 & $31: 36$ \\
\hline & & & 328 в & 396в & 253 в & 253 в & 2466 & - & $40: 16$ \\
\hline & $\Gamma$ & $280 \mathrm{~B}$ & 328 в & 396в & 253в & 253в & 3021 & - & $50: 21$ \\
\hline \multirow{6}{*}{ II } & \multirow{2}{*}{ A } & $30+150 \mathrm{~B}$ & $35 \mathrm{~B}+60$ & $105 B+60$ & $210 B+60$ & $70 \mathrm{~B}+60$ & 1347 & 270 & $26: 57$ \\
\hline & & $280 \mathrm{~B}$ & $328 \mathrm{~B}$ & 296B & 253в & 253 B & 2287 & - & $38: 07$ \\
\hline & \multirow[b]{2}{*}{ Б } & \multirow{2}{*}{$300 \mathrm{~B}$} & $60+40 B$ & $110 \mathrm{~B}+60$ & $225 B+60$ & $75 B+60$ & 1886 & 240 & $35: 26$ \\
\hline & & & 351в & 425 в & 271в & 271в & 2754 & - & $45: 54$ \\
\hline & \multirow{2}{*}{ B } & \multirow{2}{*}{$300 \mathrm{~B}$} & 351в & $60+110 \mathrm{~B}$ & $225 B+60$ & $75 \mathrm{~B}+60$ & 2500 & 180 & $44: 40$ \\
\hline & & & & 425 в & 271в & 271в & 3057 & - & $50: 57$ \\
\hline \multirow{5}{*}{ III } & \multirow{2}{*}{ A } & \multirow{2}{*}{$300 \mathrm{~B}$} & \multirow{2}{*}{351 в } & $60+115$ B & $230 B+60$ & $75 \mathrm{~B}+60$ & 2490 & 180 & $44: 30$ \\
\hline & & & & 425 в & 271в & 271в & 3037 & - & $50: 37$ \\
\hline & \multirow{2}{*}{ Б } & \multirow{2}{*}{$300 \mathrm{~B}$} & \multirow{2}{*}{ 351в } & \multirow{2}{*}{425 в } & $60+230 \mathrm{~B}$ & $75 \mathrm{~B}+60$ & 3048 & 120 & $52: 48$ \\
\hline & & & & & 271в & 271в & 3285 & - & $54: 45$ \\
\hline & B & $300 \mathrm{~B}$ & $351 \mathrm{~B}$ & 425 в & 271в & 271B & 3487 & - & $58: 07$ \\
\hline
\end{tabular}




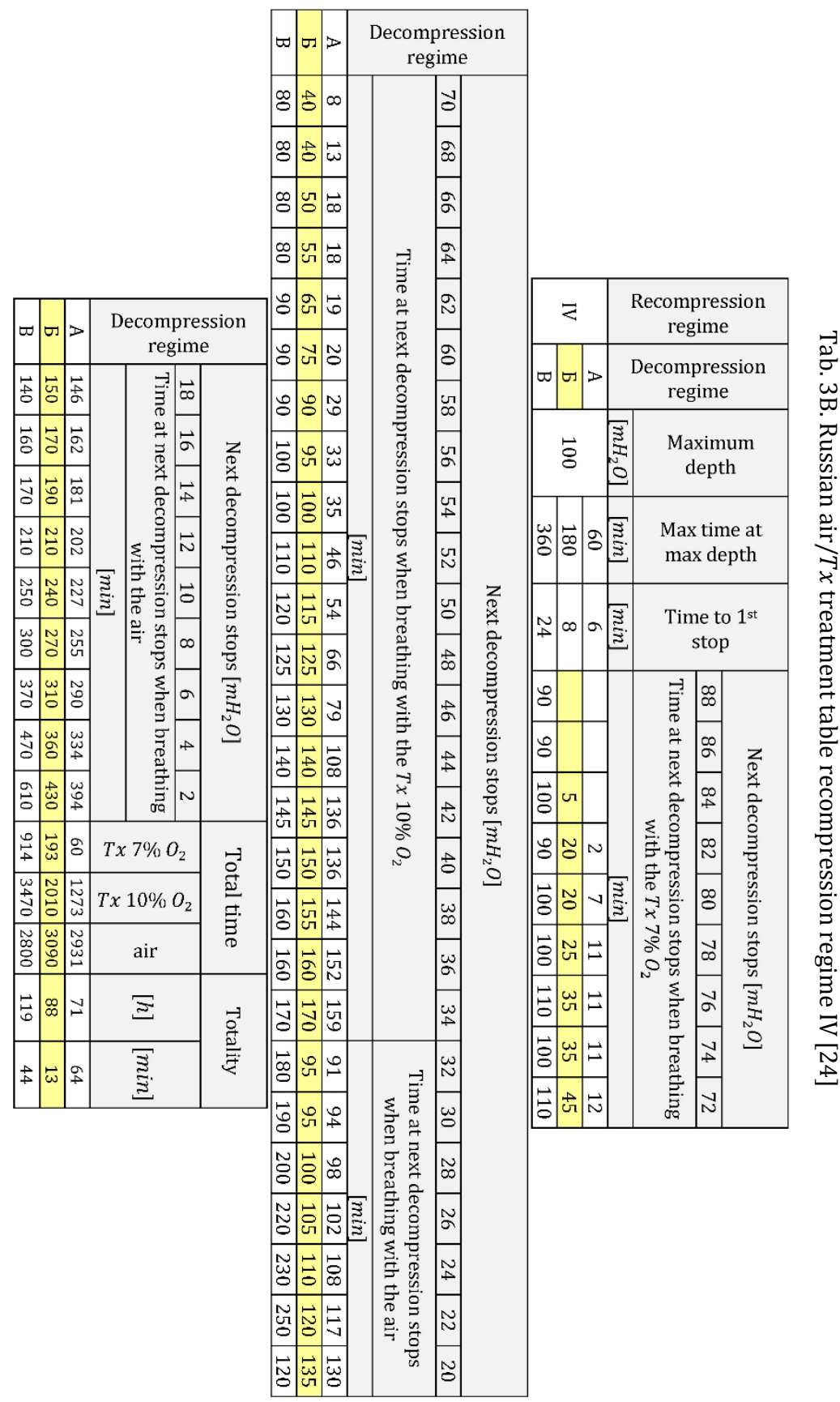




\section{COMEX TREATMENT TABLES}

Treatment tables of the French firm COMEX constitute the base for treating the most severe $D C S$ forms which can occur during both saturated diving and outside the saturation zone, to the maximum operational depth of $450 \mathrm{mH}_{2} \mathrm{O}$ [17]. Light cases are treated out of saturation zone but more severe ones require facilities for providing saturation.

Treatment tables: TT $12_{86} C x, T T 18_{86} C x$ and TT $30_{86} C x$ are similar to the US Navy oxygen treatment tables [21]. The TT $12_{86} C x$ is used to treat light DCS symptoms and the TT $18_{86} C x$ to treat more severe Type I DCS (fig. 13 and 14). The TT $30_{86} C x$ is used to treat neurological symptoms Type II DCS (fig. 15). These tables assume pharmacological support through administering acetylsalicylic acid ${ }^{22}$ and in the case of the $T T 30_{86} C x$ also an anti-inflammatory medication, hormone medicine having inflammatory properties, and isotonic infusion liquids ${ }^{23}$.

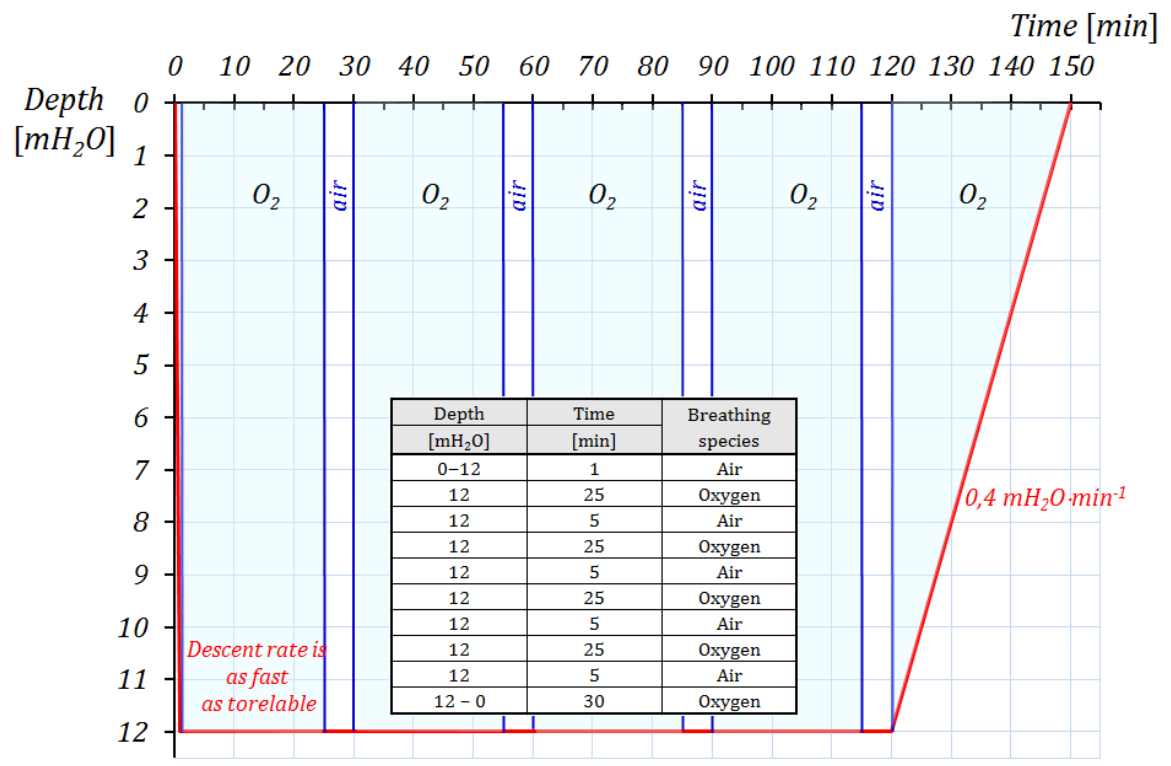

Fig. 13. Treatment table $T T 12_{86} C x[17]$

\footnotetext{
${ }^{22}$ Aspirin (Germany), Aspegic (France), Polopiryna (Poland) etc.

${ }^{23}$ Ringer's solution or balanced salt solution (physiological $\mathrm{pH}$ and isotonic salt concentration).
} 


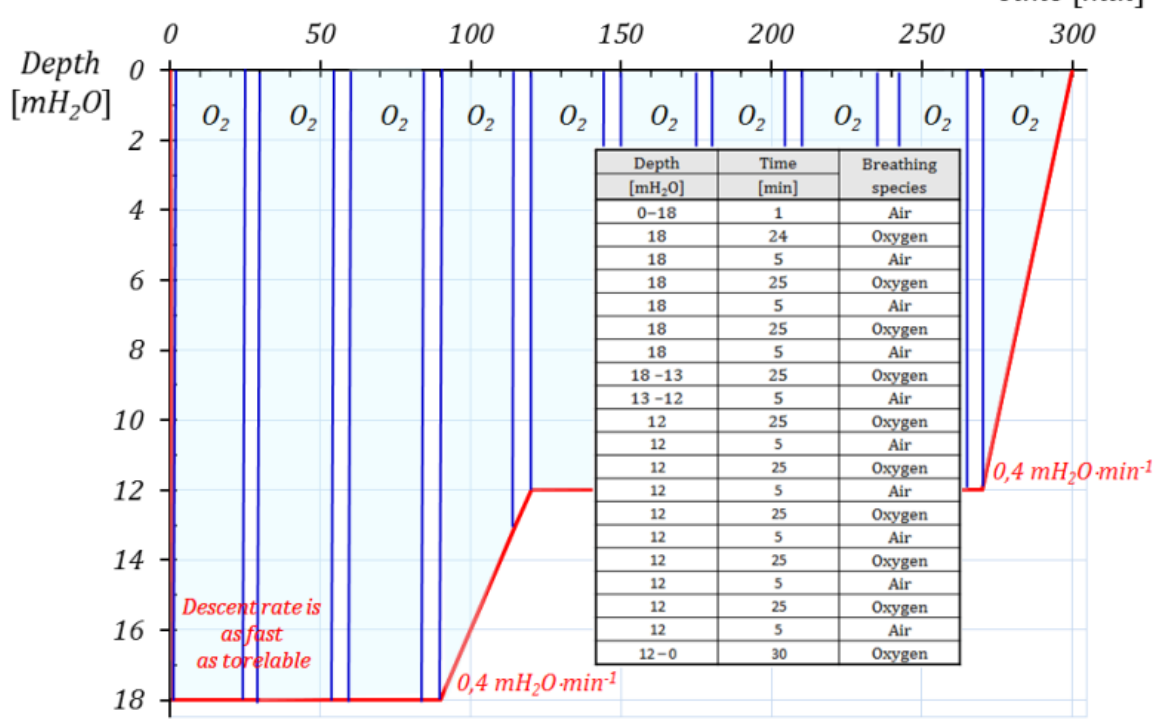

Fig. 14. Treatment table $T T 18_{86} C x[17]$

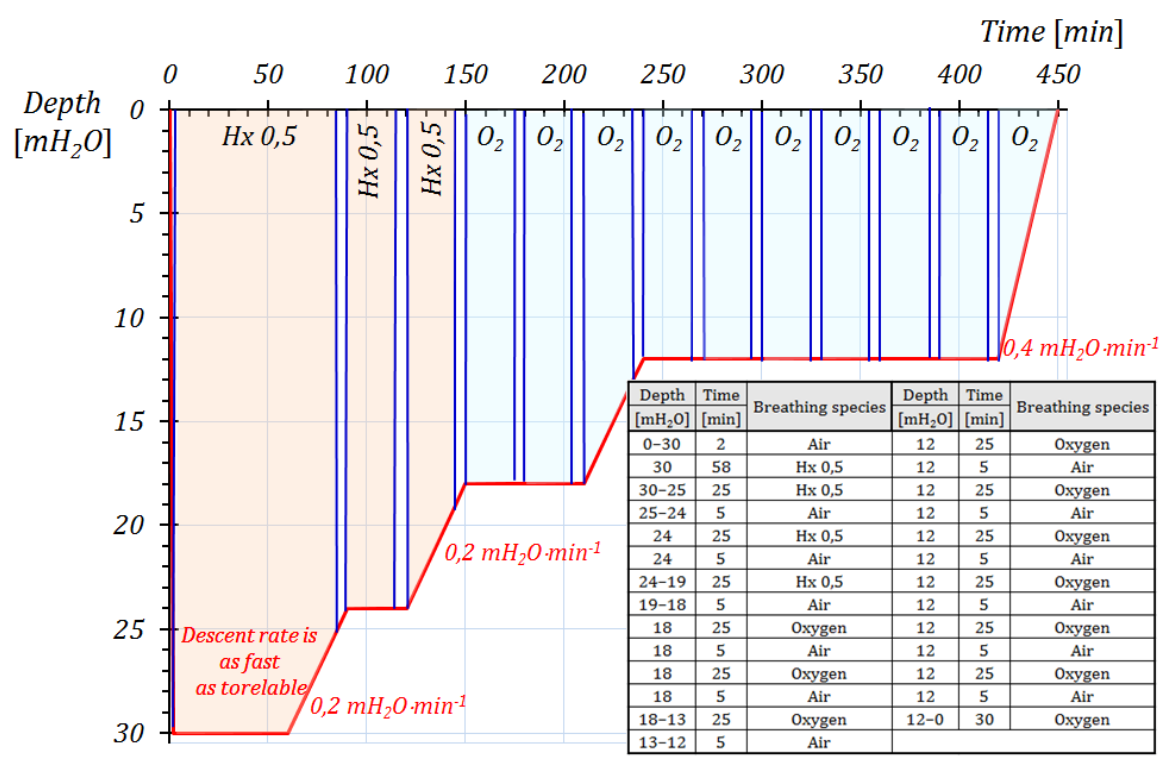

Fig. 15. Treatment table TT $30_{86} C x[17]$

Treatment tables: TT $12_{86} C x$, and TT $18_{86} C x$ constitute a treatment recompression system for symptoms Type I DCS occurring after air or $H x$ diving. If after 
$\tau=15 \mathrm{~min}$ from compression to $12 \mathrm{mH}_{2} \mathrm{O}$ DCS symptoms disapper the treatment is based on the $T T 12_{86} C x$. If this is not the case, treatment continuation is based on the TT $18_{86} C x$. Symptoms Type II DCS are treated following the TT $30_{86} C x$.

When decompression stations have been omitted or the diver has been blow up to the surface during an air dive outside the saturation zone, for Type I DCS the TT $18_{86} C x$ is used and for Type II DCS symptoms treatment is based on the TT $30_{86} C x$. If there exists a need for extending the treatment time in accordance with the TT $30_{86} \mathrm{Cx}$, the time of stop at the depth $\mathrm{H}=30 \mathrm{mH}_{2} \mathrm{O}$ can be prolonged to maximum $\tau=3 h$.

When $D C S$ occurs during air saturation or $H x$ saturation dives, or operational $H x$ diving outside the saturation zone, for Type I DCS symptoms the TT $B_{86} C x$ is used, if the symptoms disappear within $15 \mathrm{~min}$ with standard decompression, if not, the TT $S B_{86} C x$ is used with standard decompression also (tab. 4). When the condition of the diver worsens, special saturation table $T T N_{86} C x$ should be used (tab. 5).

Tab. 4. Treatment tables TT $B_{86} C x$ i TT $S B_{86} C x[17]$

\begin{tabular}{|c|c|c|c|c|c|c|c|}
\hline \multicolumn{3}{|c|}{ TT $B_{86} C x$} & \multicolumn{5}{|c|}{ TT $S B_{86} C x$} \\
\hline $\begin{array}{l}\text { Depth of } \\
\text { treatment }\end{array}$ & $\begin{array}{c}H x \\
\text { bounce } \\
\text { dive and }\end{array}$ & $\begin{array}{c}\text { Air } \\
\text { saturation }\end{array}$ & $\begin{array}{l}\text { Depth of } \\
\text { accident }\end{array}$ & $\begin{array}{l}\text { Depth of } \\
\text { treatment }\end{array}$ & $\begin{array}{c}\text { BIBS } \\
\text { breathing } \\
\text { duration }\end{array}$ & $\begin{array}{c}H x \\
\text { bounce } \\
\text { dive and }\end{array}$ & $\begin{array}{c}\text { Air } \\
\text { saturation }\end{array}$ \\
\hline$\left[\mathrm{mH}_{2} \mathrm{O}\right]$ & saturation & & {$\left[\mathrm{mH}_{2} \mathrm{O}\right]$} & {$\left[\mathrm{mH}_{2} \mathrm{O}\right]$} & {$[\mathrm{min}]$} & saturation & \\
\hline $0-12$ & Oxygen & Oxygen & $0-12$ & +6 & 120 & Oxygen & Oxygen \\
\hline $19-40$ & $H x 0,50$ & $N \times 0,50$ & $13-31$ & +9 & 120 & $H \times 0,50$ & $N x 0,50$ \\
\hline $41-110$ & $H x 0,20$ & & $32-98$ & +12 & 120 & $H x 0,20$ & \\
\hline $111-210$ & $H x 0,10$ & & 99-195 & +15 & 120 & $H x 0,10$ & \\
\hline $211-360$ & $H \times 0,05$ & & $196-345$ & +15 & 120 & $H \times 0,05$ & \\
\hline $361-450$ & $H \times 0,03$ & & $346-450$ & +15 & 120 & $H \times 0,03$ & \\
\hline
\end{tabular}

Tab. 5. Treatment table $T T N_{86} C x$ [17]

\begin{tabular}{|c|c|c|c|}
\hline \multicolumn{4}{|c|}{$T T N_{86} \mathrm{Cx}$} \\
\cline { 1 - 2 } $\begin{array}{c}\text { Depth of } \\
\text { accident }\end{array}$ & $\begin{array}{c}\text { BIBS } \\
\text { breathing } \\
\text { duration }\end{array}$ & $\begin{array}{c}\mathrm{Hx} \\
\text { bounce } \\
\text { dive and } \\
\text { saturation }\end{array}$ & $\begin{array}{c}\text { Air } \\
\text { saturation }\end{array}$ \\
\hline$\left[\mathrm{mH}_{2} \mathrm{O}\right]$ & {$[\mathrm{min}]$} & $\mathrm{N} 00,50$ \\
\hline $20-40$ & 120 & $H \times 0,50$ & \\
\hline $41-110$ & 180 & $H \times 0,20$ & \\
\hline $111-210$ & 240 & $H \times 0,10$ & \\
\hline $211-360$ & 300 & $H \times 0,05$ & \\
\hline $361-450$ & 360 & $H \times 0,03$ & \\
\hline
\end{tabular}


Saturation table TT $N_{86} C x$ is also used to treat Type II DCS symptoms following air or $H x$ saturation, or operational dives $H x$ outside the saturation zone. When using saturation table TT $N_{86} C x$ for treating cases of DCS developed during or after $H x$ dives, both saturated and outside the saturation zone, decompression is conducted on the continuous basis, with the time passage through the individual depth $t=60 \mathrm{~min} \cdot \mathrm{mH}_{2} \mathrm{O}^{-1}$ within the depth range $\mathrm{H} \in[15 ; 200] \mathrm{mH}_{2} \mathrm{O}$, keeping the oxygen partial pressure at the level $p_{\mathrm{O}_{2}} \in[60 ; 63] \mathrm{kPa}$ in $\mathrm{Hx}$ making the atmosphere of complex. Decompression from the depth $\mathrm{H}=15 \mathrm{mH}_{2} \mathrm{O}$ to the surface is conducted with the time passage through the individual depth $t=80 \mathrm{~min} \cdot \mathrm{mH}_{2} \mathrm{O}^{-1}$, keeping the oxygen volume content at the level $C_{O_{2}} \in[23 ; 24] \%_{v}$ in $H x$ making the atmosphere of complex. When treating DCS cases developed during or after saturation dives based on nitrox $\mathrm{Nx}$, for the depth range $\mathrm{H} \in[15 ; 30] \mathrm{mH}_{2} \mathrm{O}$ decompression is conducted on the continuous basis with the time passage through the individual depth $t=120 \mathrm{~min} \cdot \mathrm{mH}_{2} \mathrm{O}^{-1}$, keeping the oxygen partial pressure in $\mathrm{N} x$ making the atmosphere of complex at the level $p_{\mathrm{O}_{2}} \in[60 ; 63] \mathrm{kPa}$. From the depth $\mathrm{H}=15 \mathrm{mH}_{2} \mathrm{O}$ to the surface decompression is conducted with the passage time through the individual depth $t=180 \mathrm{~min} \cdot \mathrm{mH}_{2} \mathrm{O}^{-1}$, keeping the oxygen volume content in $\mathrm{Nx}$ making the atmosphere of complex at the level $C_{O_{2}} \in[23 ; 24] \%{ }_{v}$.

As there are no special procedures for cases when DCS symptoms appear during decompression in water, as is the case in other systems ${ }^{24}$, when they appear, the decompression is discontinued. The diver is brought to the surface as quickly as possible and further treatment is administered as in the case when a diver is blow up to the surface.

\section{DISCUSSION}

The commonly used worldwide dive decompression tables usually allow for only a low workload of the diver underwater ${ }^{25}$. This is caused by the existence, in hyperbaric conditions, of an additional workload of the respiratory system and action of the water environment itself. For example, divers use suits in which work requires additional effort, or because they cannot breathe water divers have to carry substantial amount of breathing agent, which requires additional effort concerned

\footnotetext{
${ }^{24}$ For example [21].

25 Almost without doing any extra work except diving.
} 
with carrying it, etc. Only some of the decompression tables take into account additional effort dedicated to useful work under water determining its maximum border as a mean load. This limitation is associated not only with performing work concerned with staying in the water environment itself but also with the necessity to later undergo decompression. The decompression process will be disturbed by metabolism products, which occur after the high effort is undertaken. For example, acidification of muscles with lactic acid caused by anaerobic changes leads to acidification of blood and because of this hemoglobin loses its capacities of carrying oxygen [13]. This hampers gas exchange and as a result it disturbs the process of decompression. The precise consideration of the effect workload on the panned decompression is very difficult. Only saturation dives give divers the possibility to make relatively big efforts as their decompression process is separated from the work period by suitably long rest period dedicated to stabilization.

As it was mentioned in the previous articles of the series dedicated to the issues of rescuing survivors who have been stuck in air traps in a wreck of a sunken surface vessel, mobilization of search and rescue assets fast enough to prevent the casualties from the $N x$ saturation ${ }^{26}$ is not possible. Work in the wreck will be connected with necessary mechanical separation actions ${ }^{27}$ or other requiring much physical effort. There exists a high probability for a diver to get stuck inside the wreck during the penetration. In a rescue operation support, divers, who work outside the saturation zone, due to bad decompression, face a hazard of e.g. blow up to the surface without decompression or emergency omitting some elements of decompression. The issues concerned with adopting appropriate treatment procedures with regard to divers taking part in a rescue operation is an important element of the preparation for conduct of underwater rescue. Hence the above analyses of the possible to apply treatment tables systems have been focused on these issues. The issues relating to decompression of casualties who were exposed to $N x$ saturation inside the wreck of a sunken vessel will be presented further in the series of the articles.

It follows from the carried out analysis that it is relatively easy to select the treatment recompression system for DCS cases, which occurred in the course of short-term operational dives ${ }^{28}$ outside the sub-saturation or full saturation zone. Out of many existing systems the most common is the system developed and published by the US Navy [21]. It can be used to support the DCS treatment process in divers,

${ }^{26}$ Even if mobilization is carried out relatively quickly, actions conducted by $S A R$ will not enable fast commencement of underwater rescue [6].

27 Counter fencing, removing separation barriers.

${ }^{28}$ Except for severe cases when the diver was thrown to the surface. 
providing support to saturation divers in the course of wreck penetration. Such divers can be employed to provide assistance in straightening and winding umbilicals $^{29}$ of the saturation diver and underwater vehicles, deliver tools, render assistance in transporting casualties and in other support actions carried out outside the sub-saturation and full saturation zone. These methods can also be used to treat light $D C S$ occurred after saturation diving with $N x$. The US Navy system does not allow exceeding $70 \mathrm{mH}_{2} \mathrm{O}$ to produce the relief effect in a patient. Such situations occur rarely and theoretically, and in the case of the considered operational scenario, assuming the maximum operational depth of $30 \mathrm{mH}_{2} \mathrm{O}$ they probably not occur. Extending the US Navy system by air tables system BM $\Phi$ offers additional treatment capabilities, enabling covering the cases of $D C S$ which can potentially occur during DiveSMART operations. However, the treatment is conducted in difficult conditions, hard to accept without any doubt. Complications will appear when respiratory failure occurs in in the casualty, e.g. as a result of pulmonary barotrauma ${ }^{30}$, which occurs when the diver is blow up to the surface. In such a case effective breathing $T x, N x$ or oxygen under high pressure can cause airway resistance in the patient so high that it not only will hamper the treatment process but it also may prevent him from breathing and induce asphyxia ${ }^{31}$. When this is the case, using $H x$ may turn out necessary. It should be borne in mind, however, that transfer from the heavy breathing agent to a lighter one often causes occurrence of DCS symptoms through counterdiffusion, even if this is not accompanied by change in pressure $[3-5,8]$. It seems that in the case of the DiveSMART project the use of all the three presented systems should be given a serious consideration. A comparative analysis of the proposed tables, based on one selected approach to estimation of DCS hazard, is worth conducting.

Treatment of Type I DCS and Type II DCS cases is based, first of all, on hyperbaric method. The first treatment parameter is pressure causing compression of gas in free phase precipitated in tissues allowing it to dissolve in fluids existing in tissues. This causes a decrease in mechanical impact of gas on tissues, unblocking blood flow through capillaries, cessation of response reaction of the immunity system identifying gas bubbles as aggressors.

The second parameter is time needed for homeostasis, resorption of gas in tissues and bodily fluids, and transport of dissolved gas excess to the blood. Then eliminating the gas excess from the body during the decompression by the blood prefunding the bodily tissues and lung tissue (fig. 16).

\footnotetext{
${ }^{29}$ Umbilicals.

30 Pulmonary barotrauma.

31 Insufficient amount of oxygen in the body leading to loss of consciousness.
}

1 (212) 2018 


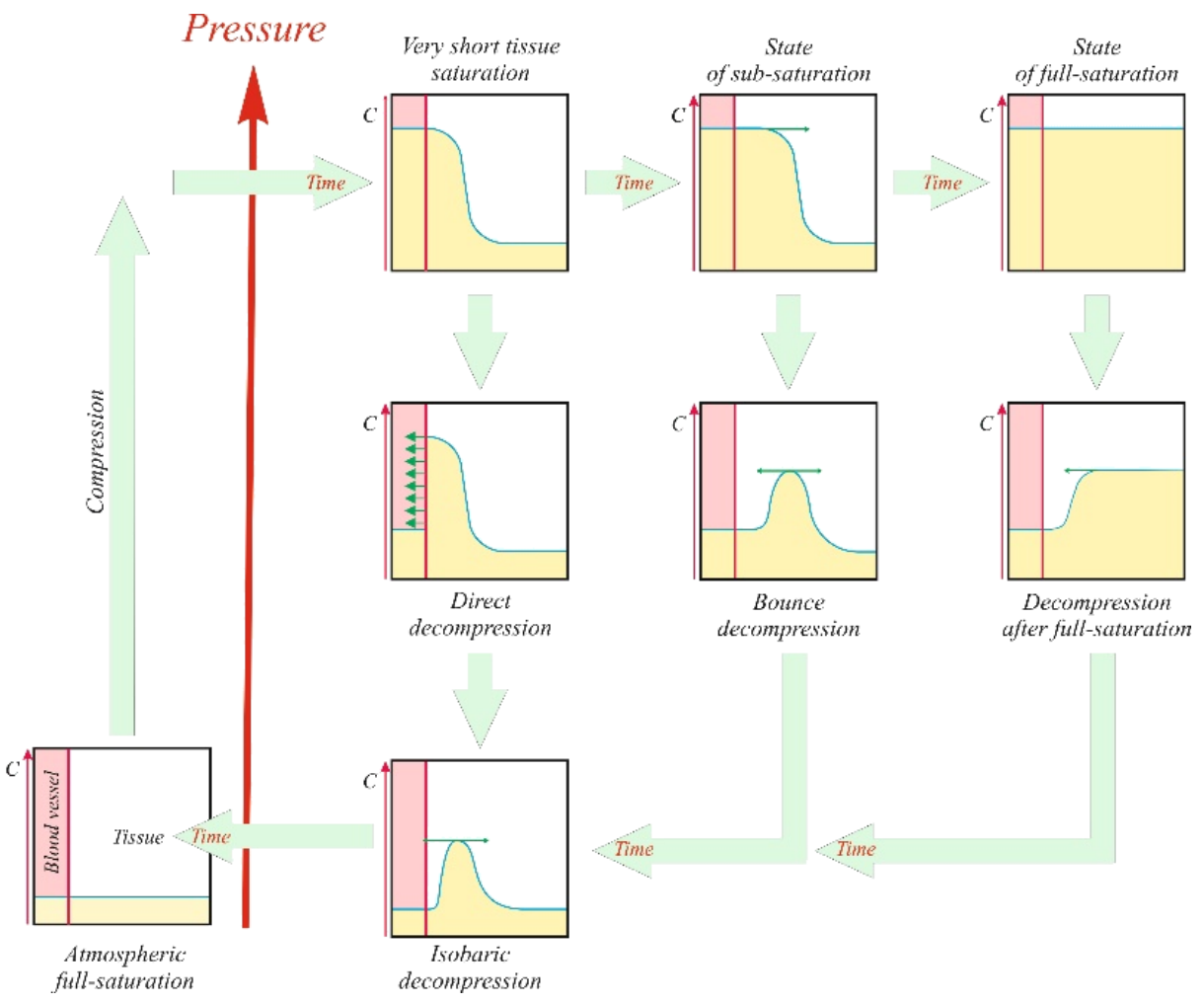

Fig. 16. Main overview for overload of inert gas in body tissues in the hyperbaric environment and its elimination during the decompression process [own study]

The factor intensifying the treatment process is the use of oxygen or mixtures enriched with oxygen. Oxygen is rapidly metabolized in the body tissues leaving a free space to transport inert gas by the blood. Sometimes, other drugs are needed in emergency cases and for the treatment intensification. The therapeutic recompression process can be supported pharmacologically by blood thinning, maximizing hydration, administering pain killers, anti-coagulants ${ }^{32}$ and anti-inflammatory medication.

Described here, the systems of treating DCS with therapeutic recompression constitute a vivid example of uses of these briefly presented parameters. But free use of pressure, time and composition of breathing agent is often made difficult because of the phenomenon of oxygen toxicity, counterdiffusion, respiratory failure, etc.

${ }^{32}$ Anticoagulants are medicines that reduce the ability of the blood to clot. 
Modelling counterdiffusion has, so far, not resulted in developing a comprehensive theory taking counterdiffusion into account during the decompression process, despite the fact that counterdiffusion cases often occur in diving [7, 23]. The occurrence of $D C S$ cases accompanied by counterdiffusion can be divided into two forms: $S I C D^{33}$ and DTICD ${ }^{34}$. The SICD symptoms occur when the diver is breathing a gas different than gas surrounding the body [15]. For example, in the Polish Navy the deep diving technology is used with $T x$ as a breathing agent during work performed under water, and the drysuit is inflated with air. During decompression the diver changes the breathing agent into air during the transfer under pressure and then into oxygen decompression. In all divers light skin DCS symptoms occur, e.g. general skin itching. The DTICD symptoms accompany sequential changes in the breathing agent, usually during decompression. The sequential changes in the breathing agent from lighter to heavier mixture and from heavier to lighter mixture can cause $D C S$, even if they are not accompanied by changes in depth $-I C D^{35}$. A combination of counterdiffusion phenomena through cell membranes and dissolution of gases in tissues can lead to exceeding the dissolution border and the precipitation of gas in free phase in tissues, causing $D C S$, due to the differences in diffusion and solubility coefficients especially of helium and nitrogen [9].

A possible counterdiffusion occurrence has to be taken into account when the US Navy method is used for treatment after an accident during deep diving or saturation diving. When the treatment methods recommended by the French firm COMEX are used the probability of counterdiffusion occurrence can be minimized by choosing for treatment the breathing agent on which DCS symptoms occurred.

\section{Acknowledgements}

I would like to thank for help to retired Cpt(Navy) Stanisław Skrzyński, PhD and retired Cdr Maciej Konarski, PhD.

\section{REFERENCES}

[1] Berghage T. E., Vorosmarti Jr. J., Barnard E. E. P., Recompression Treatment Tables Used Throughout the World by Government and Industry, NMRI 78-16, US Naval Medical Research Center, Bethesda Maryland 1978.

\footnotetext{
${ }^{33}$ Superficial Isobaric Counterdiffusion.

${ }^{34}$ Deep Tissue Isobaric Counterdiffusion.

35 Isobaric Counterdiffusion.
}

1 (212) 2018 
[2] Doolette D. J., Mitchell S. J., Biophysical basis for inner ear decompression sickness, 'J. Appl. Physiol.', 2003, 94, pp. 2145-2150.

[3] Hamilton R. W., Adams G. M., Harvey C. A., Knight D. R., SHAD-NISAT: A composite study of simulated shallow saturation diving, report No. 985, Naval Submarine Medical Research Laboratory Submarine Base, Groton 1982.

[4] Harvey C. A., Shallow saturation hyperbaric exposures to nitrogen-oxygen environments and isobaric switches to helium-oxygen, Abstract of the 'Annual Scientific Meeting', Hyperbaric Medical Society, Inc., Toronto 1977.

[5] Hyldegaard 0., Jensen T., Effect of heliox, oxygen and air breathing on helium bubbles after heliox diving, Undersea \& Hyperbaric Medical Society, 'UHMS Journal', 2007, 34, pp. 107-122.

[6] IAMSAR MANUAL International Aeronautical and Maritime Search and Rescue manual, IMO Publishing, London 2016.

[7] Imbert J.-P., Proposition of a perfusion limited model for isobaric counterdiffusion, report No. 07-01-1975, University of Pennsylvania Medical Center, Philadelphia 1975.

[8] Isobaric inert gas counterdiffusion, ed. R. C. Lambertsen, C. J. Bornmann, The Twenty-Second UHMS Workshop, Undersea Medical Society, UMS Publication No. 54WS(IC)1-11-82, Philadelphia 1979.

[9] Karreman G., Lambertsen C. J., Kinetics of isobaric counterdiffusion, 'Bulletin of Mathematical Biology', 1977, 39, pp. 587-595.

[10] Kłos R., Aparaty nurkowe z regeneracją czynnika oddechowego, COOPgraf, Poznań 2000 [Dive equipment with regeneration of the respiratory factor — available in Polish].

[11] Kłos R., Helioksowe nurkowania saturowane - podstawy teoretyczne do prowadzenia nurkowań i szkolenia, second edition, Polskie Towarzystwo Medycyny i Techniki Hiperbarycznej [Polish Society of Hyperbaric Medicine and Technology], Gdynia 2014 [Heliox carbonated dives theoretical basics for conducting dives and training — available in Polish].

[12] Kłos R., Konarski M., Olszański R., The implementation of factor analysis for the evaluation of selected blood parameter changes induced by hyperbaric exposure, 'International Maritime Health', 2004, 55, pp. 87-101.

[13] Kłos R., Możliwości doboru ekspozycji tlenowo-nitroksowych dla aparatu nurkowego typu AMPHORA — założenia do nurkowań standardowych i eksperymentalnych, Polskie Towarzystwo Medycyny i Techniki Hiperbarycznej [Polish Society of Hyperbaric Medicine and Technology], Gdynia 2012 [Possibilities of selection of oxygen-nitrox exposures for the AMPHORA dive device - assumptions for standard and experimental dives — available in Polish].

[14] Kłos R., Planning special combat operations with the use of the AMPHORA rebreather, 'Polish Hyperbaric Research', 2012, 38, pp. 29-130.

[15] Lambertsen C. J., Idicula J., A new gas lesion syndrome in man, induced by 'isobaric gas counterdiffusion', 'J. Appl. Physiol.', 1975, 39, pp. 434-443.

[16] Lambertsen C. J., Studies in isobaric counterdiffusion, Institute for Environmental Medicine, Filadelfia 1986.

[17] Medical Book, Comex, Marseille 1986.

[18] NATO Standardization Agreement STANAG 1432 UD, Allied guide to diving medical disorders, edition 4, NSO(NAVAL)1053(2014)UD/1432, NATO Standardization Office, Brussels 2014.

[19] Standards Related Document, Allied guide to diving medical disorders — national information, edition A version 1, ADivP-02.1, 2016. 
[20] Strauss R. H., Diving medicine, Grune \& Stratton Inc., New York 1976.

[21] US Navy diving manual, The Direction of Commander: Naval Sea Systems Command, group work (revision 7), SS521-AG-PRO-010 0910-LP-115-1921, 2011.

[22] Wienke B. R., Basic decompression theory and application, Best Publishing Co., Flagstaff 2003.

[23] Wienke B. R., Technical diving in depth, Best Publishing Co., Flagstaff 2001.

[24] Справочник специалиста аварийно-спасательной службы ВМФ, часть 3, ред. Н. П. Чикер, Военное издателство МО СССР, Москва 1968 [The reference book of the specialist of the rescue service of the Navy, part 3, ed. N. P. Chiker, Military Publishers of the USSR Ministry of Defense, Moscow 1968 - available in Russian].

\section{MET ODY LECZENIA \\ CHOROBY DEKOMPRESY JNEJ \\ ZAIST NIALEJ PODCZAS PENETRACJI WRAKU}

\section{STRESZCZENIE}

Artykuł należy do serii dotyczącej projektu DiveSMART, który jest związany z zapewnieniem lepszej koordynacji międzynarodowej akcji ratownictwa podwodnego w rejonie Morza Bałtyckiego. Projekt ten otrzymał status „projektu flagowego".

Artykuł jest trzecim z cyklu artykułów opisujących zadania realizowane przez Akademię Marynarki Wojennej w ramach projektu DiveSMART Baltic. Zawiera opis scenariuszy leczenia potencjalnych przypadków choroby dekompresyjnej zaistniałej u nurków podczas akcji ratowniczej lub po dekompresji. Tematyka ta dotyczy realizacji zadania czwartego 'Medical treatment' of the DiveSMART Balitc project: Identifies methods for different medical treatments in operational areas.

Słowa kluczowe:

SAR, poszukiwania i ratownictwo podwodne.

Article history

Received: 21.09 .2017

Reviewed: 08.01 .2018

Revised: $\quad 05.02 .2018$

Accepted: $\quad 06.02 .2018$

1 (212) 2018 